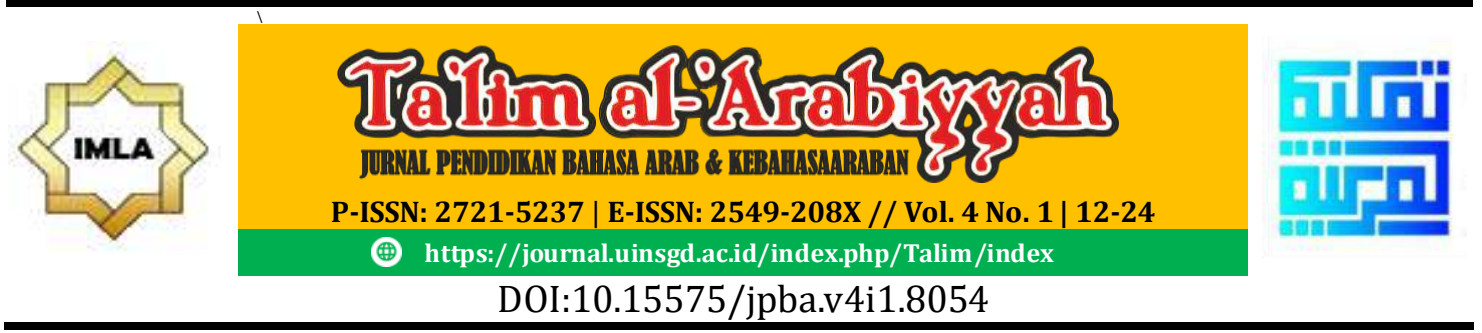

\title{
ANALISIS BUTIR SOAL BAHASA ARAB UJIAN AKHIR MADRASAH BERSAMA DAERAH (UAMBD) MADRASAH IBTIDAIYAH TAHUN 2017 - 2018
}

\author{
Deni Maulana ${ }^{1}$, Anwar Sanusi ${ }^{2}$ \\ ${ }^{1,2}$ Universitas Pendidikan Indonesia, Indonesia \\ Corresponding E-mail: denimaulana93@upi.edu
}

\begin{abstract}
This study aims to analyze the Arabic question items for the end of the regional joint madrasah (UAMBD) exam for Madrasah Ibtidaiyah (MI) students for the 2017-2018 Academic Year. After conducting research using qualitative descriptive methods with purposive sampling techniques. The result showed that (1) the validity of the contents of the Arabic UAMBD MI Year 2018 shows a very high. This is showed by the level of 100\% compatibility of all the items with the specified lattice; (2) UAMBD MI year 2018 Arabic questions have a bigh level of reliability or consistency, with a test score of 0.68 (at intervals of 0.60-0.80). It can be stated that the use of Arabic in UAMBD in 2018 can be trusted. If the results in terms of difficulties are $63.23 \%(0.63)$, it can be said to a standard test; (3) the difference in power shows it is acceptable at $31.4 \%$ and acceptable but needs to be improved at 25.7\%; and (4) the distribution of 11 question items in Arabic UAMBD MI 2018 bas a very good distribution of answer choices (distractors/deceivers); five good questions; six items lacking; nine bad questions; and four items are terrible.
\end{abstract}

Keywords: Arabic Question, Final Examination, Madrasah Ibtidaiyah, UAMBD.

\section{ABSTRAK}

Penelitian ini bertujuan untuk menganalisis butir soal bahasa Arab ujian akhir madrasah bersama daerah (UAMBD) bagi siswa Madrasah Ibtidaiyah (MI) Tahun Ajaran 2017-2018. Setelah dilakukan penelitian dengan menggunakan metode deskriptif kualitatif dengan teknik purposive sampling. Peneliti memperoleh temuan bahwa (1) validitas isi soal bahasa Arab UAMBD MI Tahun 2018 menunjukan sangat tinggi. Hal ini ditunjukan dengan tingkat kesesuaian 100\% seluruh butir soal tersebut dengan kisi-kisi yang telah ditetapkan; (2) soal bahasa Arab UAMBD MI Tahun 2018 ini memiliki tingkat reliabilitas atau tingkat konsistensi yang tinggi, dengan angka tes 0,68 (berada pada interval 0,60-0,80). Dapat dinyatakan bahwa soal bahasa Arab pada UAMBD Tahun 2018 dapat dipercaya kegunaannya. Apabila hasil ditinjau dari segi kesulitan adalah $63.23 \%(0,63)$, dapat dikatakan dapat digunakan sebagai tes standar; (3) daya beda menunjukkan dapat diterima baik mencapai $31,4 \%$ dan dapat diterima tapi perlu diperbaiki mencapai 25,7\%; dan (4) penyebaran soal sebanyak 11 butir soal bahasa Arab UAMBD MI Tahun 2018 memiliki penyebaran pilihan jawaban (distractor/pengecoh) sangat baik; sebanyak lima butir soal baik; sebanyak enam butir soal kurang; sebanyak sembilan butir soal buruk; dan empat butir soal sangat buruk.

Kata Kunci: Madrasah Ibtidaiyah, Soal Bahasa Arab, UAMBD, Ujian Akhir. 
Ta'lim al-'Arabiyyah : Jurnal Pendidikan Bahasa Arab dan Kebahasaaraban, 4 (1), 2020

\section{PENDAHULUAN}

Tes adalah alat atau prosedur yang dipergunakan dalam rangka pengukuran dan penilaian; testing berarti saat dilaksanakannya atau peristiwa berlangsungnya pengukuran dan penilaian (Ainin, 2016). Kiranya dapat dipahami dalam dunia pendidikan tes juga bisa dikatakan cara yang dapat dipergunakan dalam rangka pengukuran dan penilaian di bidang pendidikan, yang berbentuk pemberian tugas baik berupa pertanyaan-pertanyaan yang harus dijawab atau perintah-perintah yang harus dikerjakan sehingga dapat dihasilkan nilai yang melambangkan tingkah laku atau prestasi tes (Kadir, 2015).

Tes bahasa, khususnya tes bahasa Arab merupakan alat untuk mengukur kemampuan dan performansi bahasa Arab siswa (Ma'arif, 2018). Menurut Sri (Suharti, 2017) pengukuran didefinisikan sebagai penetapan suatu angka terhadap suatu subjek dengan cara sistematik. Hasil pengukuran yang berupa angka/skor diharap mencerminkan kemampuan peserta tes sebenarnya (Wahab, 2015).

Sedangkan evaluasi adalah kegiatan atau proses penentuan nilai pendidikan, sehingga dapat diketahui mutu atau hasil-hasilnya (Matsna, 2015). Senada dengan (Ridho, 2018) evaluasi merupakan salah satu komponen penting dalam pendidikan, khususnya evaluasi hasil pembelajaran. Aktivitas pendidikan menuntut adanya pengalaman belajar dari peserta didik, yang dimaksudkan untuk mencapai tujuan (menguasai kompotensi tertentu) (Hidayat, 2018). Di sinilah penilaian dibutuhkan untuk melihat sejauh mana kompetensi yang telah dikuasai oleh peserta dalam bentuk hasil belajar yang diperlihatkan setelah mereka menempuh pengalaman belajar (Zulkifli, 2018).

Apabila penilaian merupakan salah satu bagian penting dalam rangkaian proses pembelajaran dalam pendidikan (Nurgiyantoro, 2013), maka setiap pembelajaran perlu dilakukan penilaian (Wahab, 2016). Oleh karenanya penilaian hasil belajar dapat menentukan baik tidaknya pendidikan. Sehingga, ketepatan penilaian hasil belajar memberikan dampak yang sangat signifikan terhadap upaya peningkatan mutu pendidikan di sekolah (Khafidin, 2014).

Keterkaitan antara tes, pengukuran dan penilaian adalah hasil belajar baru dapat dilakukan dengan baik dan benar jika menggunakan informasi yang diperoleh melalui pengukuran hasil belajar dengan menggunakan tes sebagai alat ukurnya (Rudin, 2016). Tes yang baik harus memenuhi validitas rasional yaitu validitas isi dan validitas konstruk dan validitas empirik (Bahri, 2019). Kegunaan tes pengukuran dan penilaian dalam pendidikan antara lain adalah untuk seleksi, penempatan, diagnosa, remedial, umpan balik, motivasi dan membimbing, perbaikan Kurikulim, program pendidikan serta pengembangan ilmu (Ainin, 2019).

Dalam evaluasi pembelajaran, butir soal adalah salah satu instrument untuk melakukan penilaian (Machmudah, Khuzaimah, \& Sholihah, 2019), terutama penilaian 
Ujian Akhir Madrasah Bersama Daerah (UAMBD) sehingga suatu butir soal harus betul-betul memiliki kualitas baik agar hasil penilaian benar-benar terukur.

Sedangkan analisis butir menurut (Maimun, 2011) adalah uji lapangan dari suatu tes atau soal. Keberadaannya sebagai alat konfirmasi kualitas soal. Setelah diketahui bahwa soal tersebut lemah dalam hal daya beda, terlalu sukar atau terlalu mudah serta pengecohnya buruk maka itu harus jadi umpan balik bagi pembuat tes untuk melihat ulang kesalahan apa yang terjadi pada soal tersebut (Mahfudhah, 2017). Analisis butir dapat dilakukan secara kualitatif, dalam kaitannya dengan ciri-ciri statistiknya, (Susanty, 2016).

Butir soal objektif dapat dianalisis secara lebih akurat dan bertanggung jawab sehingga dapat diketahui kelemahannya secara tepat. Butir soal tes objektif dapat digunakan berulang-ulang, asalkan tidak dalam perangkat tes yang sama (Muslim, 2017). Oleh karena itu, ada manfaat atau kegunaan analisis butir soal, kemudian direvisi sehingga butir soal yang kurang baik kontruksinya dapat diperbaiki (Kadir, 2015). Akhirnya akan diperoleh butir soal yang telah diuji dan secara akurat mengukur hasil belajar yang ingin diukur. Untuk mempermudah menganalisis suatu tes tersebut maka diperlukan alat bantu bagi para guru dan calon guru untuk mempermudah menganalisis hasil butir soal. Salah satu alat bantu tersebut adalah software ANATES yang bisa digunakan untuk menganalisa kualitas butir soal tersbut.

Terkait Ujian Madrasah, sejak tahun Pelajaran 2009/2010 Kementrian Agama (Kemenag) telah melakukan Ujian Akhir Madrasah Berstandar Nasional (UAMBN) untuk materi soal Bahasa Arab, di samping untuk seluruh materi soal dalam rumpun Pendidikan Agama Islam (PAI) yang meliputi Al-Qur'an Hadist, Akidah Akhlak, Fiqih dan Sejarah Kebudayaan Islam (SKI). UAMBN ini berlaku untuk semua jenjang pendidikan di MI, MTs, dan MA. Pemberlakuan UAMBN ini bertujuan untuk memperkuat ciri khas madrasah dalam pendidikan agama Islam dalam bahasa Arab di seluruh jenjang pendidikan madrasah. Oleh karena itu, soal-soal untuk UAMBN ini dibuat oleh pusat dengan melibatkan KKG (Kelompok Kerja Guru) untuk MI, dan melibatkan MGMP (Musyawarah Guru Mata Pelajaran) untuk MTs dan MA.

Terkait dengan itu, timbul pentanyaan apakah butir soal bahasa Arab yang diujikan pada UAMBN tersebut sudah merupakan soal yang memenuhi kriteria evaluasi atau dapat dijadikan sebagai alat untuk mengukur tingkat pemahaman seseorang. Jangan sampai terjadi kasus seorang peserta diangap gagal bukan karena tidak menguasai materi bahasa Arab yang diajarkan tapi sulit memahami soal yang diberikan dan tingkat validitas serta reliabelitas soal rendah. Apabila tidak dilakukan analisis butir soal, maka kualitas butir soal yang diujikan menjadi tidak terukur dan belum jelas kelayakannya. Hal ini disebabkan oleh pengembangan kualitas butir soal yang tidak didasarkan pada perhitungan yang baik.

Oleh sebab itu, harus dengan dilakukan analisis butir soal agar dapat membantu pengajar mengetahui apa saja hal yang berkaitan dengan pengembangan, penyusunan, 
dan penggunaan tes yang telah baik dan perlu dipertahankan. Untuk mengetahui kualitas soal-soal UAMBN ini, perlu adanya pengkajian dan penelaahan pada setiap butir soal UAMBN tersebut.

Analisis butir soal secara kualitatif dilaksanakan berdasarkan kaidah penulisan soal (tes tulis, perbuatan, dan sikap). Penelaahan ini biasanya dilakukan sebelum soal digunakan/diujikan. Aspek yang diperhatikan di dalam penelaahan secara kualitatif ini adalah setiap soal ditelaah dari segi materi, konstruksi, bahasa/budaya, dan kunci jawaban dan pedoman penskorannya (Kadir, 2015). Sedangkan analisis butir secara kuantitatif digunakan untuk menentukan karakteristik butir soal meliputi: (1) tingkat kesukaran, (2) daya beda, (3) berfungsi atau tidaknya pilihan jawaban atau pengecoh (distractors), termasuk perhitungan tentang (4) reliabilitas skor tes (Mutholib, 2016).

Pada dasarnya, penelitian tentang analisis butir soal sudah pernah dilakukan oleh peneliti sebelumnya yaitu: Zukhaira (2010) yang dituangkan pada artikelnya yang berjudul "Analisis Butir Tes Ujian Akhir Madrasah Mata Pelajaran Bahasa Arab Siswa Madrasah Aliyah Tahun Ajaran 2008-2009. Sri Suharti (2017) Kualitas Tes Bahasa Arab dan Prestasi Peserta Didik Madrasah Tsanawiyah Kabupaten Bantul (Analisis Butir Soal UAMBN Tahun Ajaran 2013-2014. Mutholib (2013) Analisis Butir Soal Bahasa Arab Ujian Akhir Madrasah Bersama Nasional (UAMBN) Bagi Siswa Madrasah Ibtidaiyah (MI) Tahun Ajaran 2012-2013.

Berdasarkan berbagai masalah di atas permasalahan utama dalam penelitian ini, peneliti akan meneliti tentang Analisis Butir Soal Bahasa Arab Ujian Akhir Madrasah Bersama Daerah (UAMBD) Bagi Siswa Madrasah Ibtidaiyah (MI) Tahun Ajaran 2017 2018. Fokus Penelitian ini adalah kualitas butir-butir dan soal-soal mata pelajaran bahasa Arab yang digunakan pada UAMBD MI tahun ajaran 2017-2018. Ditinjau dari segi validitas dan reliabilitasnya. Juga, ditinjau dari tingkat kesulitan, daya pembeda, dan penyebaran pilihan jawabannya.

\section{METODE}

Penelitian ini menggunakan metode deskriptif kualitatif, metode deskriptif kualitatif adalah mengungkapkan sebuah fakta empiris secara objektif ilmiah dengan berlandaskan pada logika keilmuan, prosedur dan didukung oleh metodologi dan teoritis yang kuat sesuai disiplin keilmuan yang ditekuni (Musthafa \& Hermawan, 2018).

Dalam penelitian ini, metode deskriptif kualitatif digunakan untuk mendeskripsikan kualitas butir-butir soal mata pelajaran bahasa Arab yang digunakan pada UAMBD Madrasah Ibtidaiyah (MI) tahun ajaran 2017-2018 dengan cara menganalisisnya dari segi validitas, relibilitas, tingkat kesulitan dan daya beda, serta penyebaran pilihan jawaban atau distraktornya. 
Populasi penelitian ini adalah siswa Madrasah Ibtidaiyah peserta UAMBD mata pelajaran bahasa Arab Tahun ajaran 2017-2018 dari kelompok kerja madrasah (KKM) MI Kecamatan Ciampea Kabupaten Bogor. Namun, Pengambilan sampel untuk penelitian ini, peneliti menggunakan teknik purposive sampling. Yaitu teknik penentuan sampel dengan pertimbanagan tertentu (Sugiyono, 2016). Untuk itu sampel dalam penelitian ini adalah 27 siswa tes dari KKM Kecamatan Ciampea Kabupaten Bogor.

Instrumen utama yang digunakan adalah peneliti sendiri, peneliti bertindak sebagai perencana, pelaksana, pengumpul data, penganalisis, dan penafsir data. Dalam penelitian ini, peneliti akan melakukan proses pengumpulan, peringkasan, dan penggunaan informasi dari jawaban siswa untuk membuat keputusan tentang setiap penilaian terkait butir-butir soal mata pelajaran Bahasa Arab pada UAMBD tingkat Madrasah Ibtidaiyah tahun Ajaran 2017-2018. Instrumen pendudukung yang digunakan dalam penelitian ini adalah program ANATES Versi 4.0.9.

\section{HASIL DAN PEMBAHASAN}

Setelah dilakukan analisis butir soal bahasa arab ujian akhir madrasah bersama daerah (UAMBD) bagi siswa madrasah ibtidaiyah (MI) tahun ajaran 2017-2018. dilihat dari segi Validitas dan reliabelitas terdapat temuan sebagai berikut.

Validitas dapat diklasifikasikan menjadi tiga yaitu: validitas isi, validitas kriteria, dan validitas konstruk (Wahab, 2017). Adapun validitas yang telaah terkait soal mata pelajaran bahasa Arab UAMBD MI Tahun 2018 ini adalah validitas isi. Prosedurnya untuk mengetahui validitas isi pelajaran bahasa Arab dengan membandingkan domain isi soal tersebut secara komprehensif dengan domain isi kisi-kisi tes yang dijadikan pijakan penyusunan.

Adapun hasil pengujian validitas isi terkait soal bahasa Arab UAMBD MI Tahun 2018 dapat ditarik kesimpulam bahwa validitas isi soal bahasa Arab UAMBD MI Tahun 2018 menunjukan sangat tinggi. Hal ini ditunjukan dengan tingkat kesesuaian 100\% seluruh butir soal tersebut dengan kisi-kisi yang telah ditetapkan.

Selanjutnya reliabilitas soal bahasa Arab UAMBD MI Tahun 2018, untuk menghitung reliabilitas tes. Yaitu dengan rumus dikembangkan oleh Spearman-Brown. Caranya dengan mengelompokkan nomor butir yang ganjil dan genap. peneliti menggunakan program software ANATES Versi 4.0.9.

Dari hasil output program software ANATES Versi 4.0.9 diperoleh angka 0,68 untuk reliabilitas soal bahasa Arab UAMBD MI Tahun 2018. Mutholib (Mutholib, 2016) menyatakan bahwa koefesiensi reliabilitas secara wajar bergerak pada interval 0,00-1,00, dengan kriteria-kriteria. 
Ta'lim al-'Arabiyyah : Jurnal Pendidikan Bahasa Arab dan Kebahasaaraban, 4 (1), 2020

Tabel 1

Reliabilitas Tes

\begin{tabular}{cc}
\hline Kategori Reliabilitas Tes & Nilai Koefesiensi Korelasi \\
\hline Sangat rendah & $0,00-0,20$ \\
Rendah & $0,20-0,40$ \\
Sedang & $0,40-0,60$ \\
Tinggi & $0,60-0,80$ \\
Sangat Tinggi & $0,80-1,00$ \\
\hline
\end{tabular}

Dengan demikian dapat disimpulkan bahwa soal bahasa Arab UAMBD MI Tahun 2018, memiliki tingkat reliabilitas yang tinggi karena berada pada interval 0,60-0,80 sehingga skor tes ini dapat dipercaya penggunaannya. Selanjutnya kualitas soal bahasa Arab UAMBD MI Tahun 2018 dari segi tingkat kesukaran, daya pembeda, dan penyebaran pilihan jawabannya.

Output perhitungan program ANATES Versi 4.0.9 tentang tingkat kesukaran butir soal bahasa Arab UAMBD MI Tahun 2018 diperoleh angka-angka sebagaimana tertuang dalam tabel berikut.

Tabel 2

Tingkat Kesukaran Butir Soal bahasa Arab UAMBD MI Tahun 2018

\begin{tabular}{cccc}
\hline $\begin{array}{c}\text { No } \\
\text { Butir }\end{array}$ & $\begin{array}{c}\text { Jumlah } \\
\text { Betul }\end{array}$ & $\begin{array}{c}\text { Tingkat } \\
\text { Kesukaran }\end{array}$ & Tafsiran \\
\hline 1 & 20 & 86.96 & Sangat Mudah \\
2 & 16 & 69.57 & Sedang \\
3 & 20 & 86.96 & Sangat Mudah \\
4 & 15 & 65.22 & Sedang \\
5 & 20 & 86.96 & Sangat Mudah \\
6 & 20 & 86.96 & Sangat Mudah \\
7 & 19 & 82.61 & Mudah \\
8 & 23 & 100 & Sangat Mudah \\
9 & 19 & 82.61 & Mudah \\
10 & 16 & 69.57 & Sedang \\
11 & 16 & 69.57 & Sedang \\
12 & 14 & 60.87 & Sedang \\
13 & 17 & 73.91 & Mudah \\
14 & 13 & 56.52 & Sedang \\
15 & 10 & 43.48 & Sedang \\
16 & 10 & 43.48 & Sedang \\
17 & 17 & 73.91 & Mudah
\end{tabular}


Ta'lim al-'Arabiyyah : Jurnal Pendidikan Bahasa Arab dan Kebahasaaraban, 4 (1), 2020

\begin{tabular}{cccc}
18 & 13 & 56.52 & Sedang \\
19 & 12 & 52.17 & Sedang \\
20 & 10 & 43.48 & Sedang \\
21 & 13 & 56.52 & Sedang \\
22 & 13 & 56.52 & Sedang \\
23 & 22 & 95.65 & Sangat Mudah \\
24 & 5 & 21.74 & Sukar \\
25 & 12 & 52.17 & Sedang \\
26 & 5 & 21.74 & Sukar \\
27 & 17 & 73.91 & Mudah \\
28 & 20 & 86.96 & Sangat Mudah \\
29 & 11 & 47.83 & Sedang \\
30 & 21 & 91.3 & Sangat Mudah \\
31 & 22 & 95.65 & Sangat Mudah \\
32 & 7 & 30.43 & Sangat Mudah \\
33 & 10 & 43.48 & Sedang \\
34 & 4 & 17.39 & Sukar \\
35 & 7 & 30.43 & Sangat Mudah \\
\hline
\end{tabular}

Dari tabel tersebut, tingkat Kesukaran butir soal dapat dilihat dari prosentase (indeks kesukaran butir/IKB) dapat bernilai 0,00-1,00; dengan Kriteria IKB: 0,00-0,20 adalah sangat sukar 0,20-0,40 sukar 0.40-0.60 sedang 0,60-0,80 mudah 0,80-1,00 sangat mudah. Dan dapat disimpulkan sebanyak 11 butir soal bahasa Arab UAMBD MI Tahun 2018 memiliki tingkat kesukaran antara 0,80-1,00; sebanyak 5 butir soal memiliki tingkat kesukaran 0,60-0,80; sebanyak 16 butir soal memiliki tingkat kesukaran 0.40-0.60; sebanyak 3 butir soal memiliki tingkat kesukaran 0,20-0,40; dan tidak ada butir soal yang memiliki tingkat kesukaran sangat sukar 0,00-0,20.

Tabel 3

Status Soal

\begin{tabular}{cc}
\hline Status Soal & Nomor Butir Soal \\
\hline Sangat Mudah & $1,3,5,6,8,23,28,30,31,32,35$ \\
Mudah & $7,9,13,17,27$ \\
Sedang & $2,4,10,11,12,14,15,16,18,19,20,21,22,25,29,33$ \\
Sukar & $24,26,34$ \\
Sangat Sukar & - \\
\hline
\end{tabular}


Ta'lim al-'Arabiyyah : Jurnal Pendidikan Bahasa Arab dan Kebahasaaraban, 4 (1), 2020

Apabila dilihat dari tabel tingkat kesukaran butir soal bahasa Arab UAMBD MI Tahun 2018 adalah 63.23 \% (0,63). Dengan demikian dapat dikatakan soal bahasa Arab UAMBD MI Tahun 2018 memiliki tingkat kesukaran yang sedang dan dapat digunakan sebagai tes standar.

Selanjutnya daya beda soal, (Al-Khuli, 2000) dalam mengklasifikasikan daya beda soal ke dalam empat klasifikasi yakni: soal diterima dengan baik jika memiliki daya beda antara 0,40 sampai dengan 1,00; soal diterima dengan perbaikan jika daya beda antara 0,30-0,39; soal harus diperbaiki jika daya beda antara 0,20-0,29; dan soal tidak terpakai jika daya beda berkisar antara 0,00-0,19.

Dari hasil perhitungan program ANATES Versi 4.0.9 diketahui sebanyak 11 butir dikatakan soal bahasa Arab UAMBD MI Tahun 2018 memiliki daya beda di atas 0,40; sebanyak 9 butir soal memiliki daya beda antara 0,30-0.39; tidak ada butir soal memiliki daya beda antara 0,20-0,29; dan sebanyak 15 butir soal memiliki daya beda 0,00-0,19 (termasuk 1 butir soal yang berdaya beda negatif). Artinya, soal bahasa Arab UAMBD MI Tahun 2018 dapat diterima baik mencapai 31,4\% dapat diterima tapi perlu diperbaiki mencapai $25,7 \%$; masih perlu diperbaiki $0 \%$ dan $42,9 \%$ butir soal yang tidak dipakai/dibuang.

Adapun rincian status butir-butir soal tersebut adalah sebagai berikut:

Tabel 4

Status Soal

\begin{tabular}{cc}
\hline Status Soal & Nomor Butir Soal \\
\hline Diterima baik & $1,2,7,9,10,11,12,14,22,32,33$, \\
Diterima tapi perlu perbaikan & $6,15,18,19,20,21,26,29,35$ \\
Perlu diperbaiki & - \\
Tidak dipakai/dibuang & $3,4,5,8,13,16,17,23,24,25,27,28,30,31,34$ \\
\hline
\end{tabular}

Secara umum dari hasil tersebut bahwa butir-butir soal bahasa Arab yang diujikan pada UAMBD MI Tahun 2018 memiliki kemampuan membedakan kelompok tes berprestasi tinggi dan kelompok tes berprestasi rendah.

Selanjutnya, penyebaran pilihan jawaban soal bahasa Arab UAMBD MI Tahun 2018. Penelaahan penyebaran pilihan jawaban soal bahasa Arab UAMBD MI Tahun 2018 dimaksudkan berfungsi atau tidaknya pilihan jawaban yang tersedia. Suatu pilihan jawaban (pengecoh) dapat dikatakan berfungsi apabila pengecoh: (1) paling tidak dipilih oleh $5 \%$ peserta tes/siswa dan (2) lebih banyak dipilih oleh kelompok siswa yang belum paham materi.

Tabel berikut adalah hasil perhitungan penyebaran pilihan jawaban (distractor/pengecoh) terhadap butir soal bahasa Arab UAMBD MI Tahun 2018 dengan menggunakan program ANATES Versi 4.0.9. 
Ta'lim al-'Arabiyyah : Jurnal Pendidikan Bahasa Arab dan Kebahasaaraban, 4 (1), 2020

\section{KUALITAS PENGECOH}

ニニニニニニニニニニニニニニニニニ

Jumlah Subyek $=23$

Butir Soal $=35$

Tabel 5

Kualitas Pengecoh

\begin{tabular}{|c|c|c|c|c|c|}
\hline No Butir & a & B & c & d & $*$ \\
\hline 1 & $1++$ & $20 * *$ & $2--$ & $0--$ & 0 \\
\hline 2 & $2++$ & 4- & $16^{* *}$ & $1-$ & 0 \\
\hline 3 & $20 * *$ & $0--$ & $1++$ & $2--$ & 0 \\
\hline 4 & 5-- & $3++$ & $0--$ & $15^{* *}$ & 0 \\
\hline 5 & $20^{* *}$ & $1++$ & $2--$ & $0--$ & 0 \\
\hline 6 & $20^{* *}$ & 3--- & 0-- & $0--$ & 0 \\
\hline 7 & $2+$ & $19 * *$ & $1+$ & $1+$ & 0 \\
\hline 8 & 0 & 0 & $23^{* *}$ & 0 & 0 \\
\hline 9 & 3--- & $1+$ & $19 * *$ & $0--$ & 0 \\
\hline 10 & $3+$ & $16^{* *}$ & $2++$ & $2++$ & 0 \\
\hline 11 & $16^{* *}$ & 6--- & $0--$ & $1-$ & 0 \\
\hline 12 & $3++$ & 6-- & $14^{* *}$ & $0--$ & 0 \\
\hline 13 & $17^{* *}$ & $2++$ & $2++$ & $2++$ & 0 \\
\hline 14 & 6-- & $1-$ & $13^{* *}$ & $3++$ & 0 \\
\hline 15 & $5++$ & $5++$ & $3+$ & $10^{* *}$ & 0 \\
\hline 16 & $10^{* *}$ & 8-- & $4++$ & 1-- & 0 \\
\hline 17 & 5--- & $1-$ & $17 * *$ & $0--$ & 0 \\
\hline 18 & $2+$ & $13^{* *}$ & 8--- & $0--$ & 0 \\
\hline 19 & $3++$ & $12^{* *}$ & $3++$ & $5+$ & 0 \\
\hline 20 & $10^{* *}$ & 1-- & $3+$ & 9--- & 0 \\
\hline 21 & $2+$ & $1-$ & 7--- & $13^{* *}$ & 0 \\
\hline 22 & $2+$ & $13^{* *}$ & $3++$ & $5+$ & 0 \\
\hline 23 & $22^{* *}$ & 1--- & 0-- & $0--$ & 0 \\
\hline 24 & $4+$ & $5^{* *}$ & $7++$ & $7++$ & 0 \\
\hline
\end{tabular}


Ta'lim al-'Arabiyyah : Jurnal Pendidikan Bahasa Arab dan Kebahasaaraban, 4 (1), 2020

\begin{tabular}{cccccc}
25 & $12^{* *}$ & $7--$ & $2+$ & $2+$ & 0 \\
26 & $0--$ & $17--$ & $1--$ & $5^{* *}$ & 0 \\
27 & $2++$ & $3+$ & $17 * *$ & $1-$ & 0 \\
28 & $0--$ & $3---$ & $20^{* *}$ & $0--$ & 0 \\
29 & $11^{* *}$ & $3+$ & $4++$ & $5++$ & 0 \\
30 & $2---$ & $0--$ & $21^{* *}$ & $0--$ & 0 \\
31 & $1---$ & $0--$ & $0--$ & $22^{* *}$ & 0 \\
32 & $7 * *$ & $6++$ & $7+$ & $3+$ & 0 \\
33 & $4++$ & $10^{* *}$ & $5++$ & $4++$ & 0 \\
34 & $12--$ & $7++$ & $4 * *$ & $0--$ & 0 \\
35 & $6++$ & $5++$ & $7 * *$ & $5++$ & 0 \\
\hline
\end{tabular}

Keterangan:

$\begin{array}{llll}* * & : \text { Kunci Jawaban } & - & \text { : Kurang Baik } \\ ++ & \text { : Sangat Baik } & -- & \text { : Buruk } \\ + & : \text { Baik } & --- & \text { : Sangat Buruk }\end{array}$

Dari tabel di atas, penyebaran pilihan jawaban yang dihasilkan dengan program ANATES Versi 4.0.9 dapat disimpulkan sebanyak 11 butir soal soal bahasa Arab UAMBD MI Tahun 2018 memiliki penyebaran pilihan jawaban (distractor/pengecoh) sangat baik; sebanyak lima butir soal baik; sebanyak enam butir soal kurang; sebanyak sembilan butir soal buruk; dan empat butir soal sangat buruk.

Adapun riciannya status butir-butir soal tersebut adalah sebagai berikut:

Tabel 6

Status Pengecoh

\begin{tabular}{cc}
\hline Status Pengecoh/Distraktor & Nomor Butir Soal \\
\hline Distraktor sangat baik (dipertahankan) & $7,10,13,15,19,22,24,29,32,33,35$ \\
Distraktor baik (dipertahankan) & $2,14,25,27,34$ \\
Distraktor kurang baik (diperbaiki) & $1,3,4,5,12,16$ \\
Distractor buruk (diganti/dibuang) & $6,9,11,17,20,21,23,30,31$ \\
Distraktor sangat buruk(diganti/dibuang) & $8,26,28,31$ \\
\hline
\end{tabular}

Dari hasil ini, secara umum dapat dikatakan bahwa butir-butir soal bahasa Arab yang diujikan pada UAMBD MI 2018 memiliki penyebaran pilihan jawaban (distractor/pengecoh) yang efektif atau berfungsi. 
Ta'lim al-'Arabiyyah : Jurnal Pendidikan Bahasa Arab dan Kebahasaaraban, 4 (1), 2020

\section{SIMPULAN}

Berdasarkan uraian di atas dapat disimpulkan kualitas butir-butir soal bahasa Arab yang digunakan pada UAMBD Madrasah Ibtidaiyah (MI) tahun ajaran 20172018 dari segi validitas dan reliabilitanya bahwa validitas isi soal bahasa Arab UAMBD MI Tahun 2018 menunjukan sangat tinggi. Hal ini ditunjukan dengan tingkat kesesuaian 100\% seluruh butir soal tersebut dengan kisi-kisi yang telah ditetapkan. Sedangkan soal bahasa Arab UAMBD MI Tahun 2018 ini memiliki tingkat reliabilitas atau tingkat keajegan/konsistensi yang tinggi, dengan angka tes 0,68 (berada pada interval 0,60-0,80). Dapat dinyatakan bahwa soal bahasa Arab pada UAMBD Tahun 2018 dapat dipercaya kegunaannya. Selanjutnya kualitas butir-butir soal bahasa Arab yang digunakan pada UAMBD Madrasah Ibtidaiyah (MI) tahun ajaran 2017-2018 dari segi tingkat kesukaran, daya beda, dan penyebaran pilihan jawabannya. Tingkat Kesukaran Butir Soal bahasa Arab UAMBD MI Tahun 2018 adalah 63.23 \% (0,63). Maka dapat dikatakan bahwa soal bahasa Arab UAMBD MI Tahun 2018 memiliki tingkat kesukaran yang sedang dan dapat digunakan sebagai tes standar. Sedangkan daya beda soal bahasa Arab UAMBD MI Tahun 2018 dapat diterima baik mencapai $31,4 \%$ dapat diterima tapi perlu diperbaiki mencapai $25,7 \%$; masih perlu diperbaiki $0 \%$ dan 42,9 butir soal yang tidak dipakai/dibuang. dari hasil tersebut bahwa butir-butir soal bahasa Arab yang diujikan pada UAMBD MI Tahun 2018 memiliki kemampuan membedakan kelompok tes berprestasi tinggi dan kelompok tes berprestasi rendah. Sementara penyebaran jawaban atau distraktor pada soal bahasa Arab UAMBD MI Tahun 2018. Dan sebanyak 11 butir soal soal bahasa Arab UAMBD MI Tahun 2018 memiliki penyebaran pilihan jawaban (distractor/pengecoh) sangat baik; sebanyak lima butir soal baik; sebanyak enam butir soal kurang; sebanyak sembilan butir soal buruk; dan empat butir soal sangat buruk. Jadi, dapat disimpulkan bahwa butir-butir soal bahasa Arab yang diujikan pada UAMBD MI 2018 memiliki penyebaran pilihan jawaban (distractor/pengecoh) yang efektif atau berfungsi. Hasil penelitian ini diharapkan akan memberikan sumbangsih bagi peningkatan kualitas pembelajaran bahasa Arab di Madrasah Ibtidaiyah dan menjadi bahan rujukan bagi penyusunan dan penggunaan soal-soal bahasa Arab pada UAMBD bagi siswa Madrasah Ibtidaiyah di masa yang akan datang.

\section{DAFTAR PUSTAKA}

Ainin, M. (2016). Evaluasi dalam Pembelajaran Bahasa Arab. Malang: Misykat.

Ainin, M. (2019). Pengembangan Kurikulum Dalam Pembelajaran Babasa Arab. Malang: Lisan Arabi.

Al-Khuli, M. A. (2000). al-Ikbtibarat al-Lughawiyyahh. Amman: Dar al-Falah.

Bahri, O. S. (2019). Analisis Isi Soal UAMBN Bahasa Arab Madrasah Aliyah Tahun 
Ta'lim al-'Arabiyyah : Jurnal Pendidikan Bahasa Arab dan Kebahasaaraban, 4 (1), 2020

Pelajaran. Educare: Jurnal Pendidikan Dan Pembelajaran, 17(1), 50-54.

Hidayat, Y. (2018). Teori Perolehan Dan Perkembangan Bahasa Untuk Jurusan

Pendidikan Bahasa Arab. Mabarat, 1(1), 28. https://doi.org/10.18196/mht.113

Kadir, A. (2015). MENYUSUN DAN MENGANALISIS TES HASIL BELAJAR. Jurnal Al-Ta'dib. https://doi.org/http://dx.doi.org/10.31332/atdb.v8i2.411

Khafidin, Z. (2014). Analisis Validitas Dan Reliabilitas Tes Mata Pelajaran Pendidikan Agama Islam Tingkat SMA. Edukasia : Jurnal Penelitian Pendidikan Islam. https://doi.org/10.21043/edukasia.v9i2.775

Ma'arif, A. S. (2018). Sighah Ikhtibarat al-'Arabiyyah fi Dui al-Ikhtibar al-Mutqn (TOAFL). Jurnal Al Bayan: Jurnal Jurusan Pendidikan Babasa Arab, 9(2). https://doi.org/10.24042/albayan.v9i2.2233

Machmudah, U., Khuzaimah, K., \& Sholihah, M. (2019). The Characteristics Of Arabic Language Textbooks Of Madrasah Ibtidaiyah. Jurnal AlBayan:Jurnal Jurusan Pendidikan Bahasa Arab, 11(1), 179-193. https://doi.org/10.24042/albayan.v11i1.4091

Mahfudhah, Z. (2017). Tablil Ikbtibarat Al-Lughah Al-'Arabiyyah (Dirasah Taqwimiyah bil Madrasah Muthawasitah Sarusy Syari'ab bi Banda Aceh). Skripsi thesis, UIN Ar-Raniry Banda Aceh.Zabratul Mahfudhah, 221222514 (2017) Tablil Ikbtibarat Al. UIN ArRaniry Banda Aceh.

Maimun. (2011). Evaluasi dalam Pembelajaran Bahasa Arab Di Stain Pamekasan. Nuansa.

Matsna, M. \& R. (2015). Evaluasi Pembelajaran Bahasa Arab. Ciputat: UIN Press.

Muslim, A. B. (2017). Al-Ikhtibarat al-Lughawiyyah: Tasmimuha wa Anwa'uha. Jurnal Al Bayan: Jurnal Jurusan Pendidikan Bahasa Arab, 8(1). https://doi.org/10.24042/albayan.v8i1.359

Musthafa, I., \& Hermawan, A. (2018). Metodologi Penelitian Babasa Arab (Konsep Dasar, Strategi, Metode, Teknik). Bandung: PT Remaja Rosakarya.

Mutholib, A. (2016). Analisis Butir Soal Bahasa Arab Ujian Akhir Madrasah Berstandar Nasional (UAMBN) Bagi Siswa Madrasah Ibtidaiyah (MI) Tahun Pelajaran 2012-2013. Arabia, 5(2).

Nurgiyantoro, B. (2013). Penilain Pembelajaran Bahasa Berbasis Kompetensi. Yogyakarta: BPEF-Yogyakarta.

Ridho, U. (2018). Evaluasi dalam Pembelajaran Bahasa Arab. An Nabighoh Jurnal Pendidikan Dan Pembelajaran Bahasa Arab. https:/ /doi.org/10.32332/annabighoh.v20i01.1124

Rudin, A. (2016). Analisis Butir Soal Ujian Kenaikan Kelas Mata Pelajaran Babasa Arab Kelas VIII Di MTs Modern Al Azhary Ajibarang Tabun Pelajaran 2015-2016 (IAIN 
Ta'lim al-'Arabiyyah : Jurnal Pendidikan Bahasa Arab dan Kebahasaaraban, 4 (1), 2020

Purwokerto). Retrieved from http://repository.iainpurwokerto.ac.id/2117/

Sugiyono. (2016). Metode Penelitian Kuantitatif Kualitatif dan R\&D. Bandung: Alfabeta.

Suharti, S. (2017). Kualitas Tes Bahasa Arab dan Prestasi Peserta Didik Madrasah Tsanawiyah Kabupaten Bantul ( Analisis Butir Soal UAMBN. Jurnal Pendidikan Madrasah, 2(1), 185-196.

Susanty, F. D. (2016). Analisis Validasi Soal Tes Hasil Belajar Pada Pelaksanaan Pembelajaran Bahasa Arab Di Pusat Pengembangan Bahasa (P3B) Uin Suska Riau. Kutubkhanah: Jurnal Penelitian Sosial Keagamaan, Vol.19, No.2.

Wahab, M. A. (2015). Pembelajaran Bahasa Arab Di Era Posmodern. ARABIYAT: Jurnal Pendidikan Bahasa Arab Dan Kebahasaaraban. https://doi.org/10.15408/a.v2i1.1519

Wahab, M. A. (2016). Standarisasi Kurikulum Pendidikan Bahasa Arab Di Perguruan Tinggi Islam Negeri. Arabiyât, 3(1), 32-51.

Wahab, M. A. (2017). Perkembangan Tes Bahasa Arab Standar di Indonesia. Arabi.

Zulkifli, M. (2018). ANALISIS BENTUK EVALUASI KURIKULUM 2013 MATA PELAJARAN BAHASA ARAB DI MI. Al-Madrasab: Jurnal Pendidikan Madrasah Ibtidaiyah. https://doi.org/10.35931/am.v0i0.29 